\title{
Chemical and isotopic snow variability along the 1998 ITASE traverse from Terra Nova Bay to Dome G, East Antarctica
}

\author{
Marco PROPOSito, ${ }^{1,4}$ Silvia BEGaGli, ${ }^{2}$ Emiliano GASTEllanO, ${ }^{2}$ Onelio Flora, ${ }^{3}$ \\ Laura Genoni, ${ }^{3}$ Roberto GRAGNani, ${ }^{4}$ Barbara STEnni, ${ }^{3}$ Rita TRAVERSi, ${ }^{2}$ \\ Roberto UDISTI, ${ }^{2}$ Massimo FREZZOTTI ${ }^{4}$ \\ ${ }^{1}$ Museo Nazionale dell'Antartide, Strada del Laterino 8, I-53100 Siena, Italy \\ E-mail:marco.proposito@casaccia.enea.it \\ ${ }^{2}$ Department of Chemistry, University of Florence, Via G. Capponi 9, I-50121 Florence, Italy \\ ${ }^{3}$ Department of Geological, Environmental and Marine Sciences, University of Trieste, Via E. Weiss 2, I-34127 Trieste, Italy \\ ${ }^{4}$ ENEA, CR Casaccia, P.O. Box 2400, I-00100 Rome, Italy
}

\begin{abstract}
In the framework of the PNRA-ITASE (Programma Nazionale di Ricerche in Antartide-International Trans-Antarctic Scientific Expedition) project, during the field season 1998/99, surface snow (1 m cores and pits) and shallow firn cores $(10-50 \mathrm{~m}$ ) were collected along a traverse from Terra Nova Bay (northern Victoria Land) to Dome C (East Antarctic ice sheet). Results of chemical, tritium and stable-isotope composition are presented here for the $1 \mathrm{~m}$ cores, some snow pits and the first $2 \mathrm{~m}$ of some shallow firn cores. The $\delta^{18} \mathrm{O}$ values show a regular trend with altitude, and the regression line between $\delta^{18} \mathrm{O}$ and surface temperature is $\delta^{18} \mathrm{O}=0.99 T\left({ }^{\circ} \mathrm{C}\right)-0.67$. Primary aerosol components such as $\mathrm{Na}^{+}, \mathrm{Cl}^{-}, \mathrm{Ca}^{2+}, \mathrm{Mg}^{2+}$ and $\mathrm{K}^{+}$show high concentrations decreasing with increasing altitude in the first $250-350 \mathrm{~km}$ from the coast. At greater distances, concentrations of these species remain more constant. $\mathrm{NO}_{3}{ }^{-}$concentration shows an irregular profile with a progressive decreasing trend as altitude increases. Non-sea-salt (nss) $\mathrm{SO}_{4}{ }^{2-}$ concentration decreases up to about $250 \mathrm{~km}$ from the coast, increases $250-770 \mathrm{~km}$ from the coast and remains relatively constant in the most remote stations. Methanesulphonate (MSA) concentration shows high variability. The MSA $/ \mathrm{nssSO}_{4}{ }^{2-}$ ratio exhibits a decreasing trend $250-550 \mathrm{~km}$ from the coast. With increasing distance, the ratio shows moderate oscillations. $\mathrm{nssCl}^{-}$concentration shows a progressive increase as distance from the coast increases, in agreement with the increasing influence of $\mathrm{HCl}$ on the $\mathrm{Cl}^{-}$budget of the inland Antarctic atmosphere. Post-depositional re-emissions of $\mathrm{Cl}^{-}$and $\mathrm{NO}_{3}{ }^{-}$were found at stations characterized at the surface by longterm accumulation hiatus (wind crusts). The chemical-species distribution is consistent with the presence in the studied area of local and long-range transport processes, post-depositional effects and snow-accumulation variations observed along the traverse.
\end{abstract}

\section{INTRODUCTION}

Information on spatial variability of snow chemistry is essential in glaciochemical studies. Some authors (Mulvaney and Wolff, 1994; Qin, 1995; Stenberg and others, 1998; Kreutz and Mayewski, 1999), reporting Antarctic glaciochemical data measured at stations characterized by different distances and elevations inland, show that there are still large areas lacking in data. Moreover, due to the high spatial variability in aerosol composition, scavenging processes, snow accumulation, wind distribution and firnification processes on regional as well as local scales, intensive research is required in order to understand the chemical-physical processes involving concentration changes of chemical species in Antarctica.

To improve knowledge of the spatial variability of climate and environmental conditions over the eastern Dome C drainage area, a traverse was performed from Terra Nova Bay (northern Victoria Land) to Dome C (East Antarctic plateau). In the framework of the PNRA-ITASE (Programma Nazionale di Ricerche in Antartide-International Trans-Antarctic Scientific Expedition) project, during the field season 1998/99, 227 samples of surface snow ( $1 \mathrm{~m}$ cores) were collected, with a spatial resolution of about
$5 \mathrm{~km}$, along a traverse route from coastal areas (GPSl) to about $1000 \mathrm{~km}$ inland (Dome $\mathrm{C}$ ), with an altitude range of 1200-3230m a.s.l. (Table 1). Thirty shallow firn cores (10$50 \mathrm{~m}$ long) and seven snow pits (about $2 \mathrm{~m}$ deep) were also sampled with a lower spatial resolution (about 70-160 km; Fig. la). Here, we report the results of chemical, tritium and stable-isotope analyses of the 227 samples of surface snow, four snow pits (M2, MP, D2 and D4) and the first $2 \mathrm{~m}$ of two shallow firn cores (M2 and M2D).

Several authors (Watanabe, 1978; Pettré and others, 1986; Goodwin, 1990; Frezzotti and others, 2002) have pointed out the influence of katabatic wind on the snow-accumulation redistribution process. This wind is the main element acting on the snow surface that causes surface ablation and snow transport/redistribution. Many types of surface features, such as sastrugi, snow dunes, pitted patterns and smoothed and glazed surfaces (wind crusts), are distributed on the surface of the Antarctic ice sheet in varying degrees of scale and occurrence as a result of interaction between the air and the ice-sheet surface. These aeolian processes affect the snow accumulation and chemical and isotopic composition during firnification. Frezzotti and others (2002) pointed out that along the traverse, erosional features (wind crust) constitute 

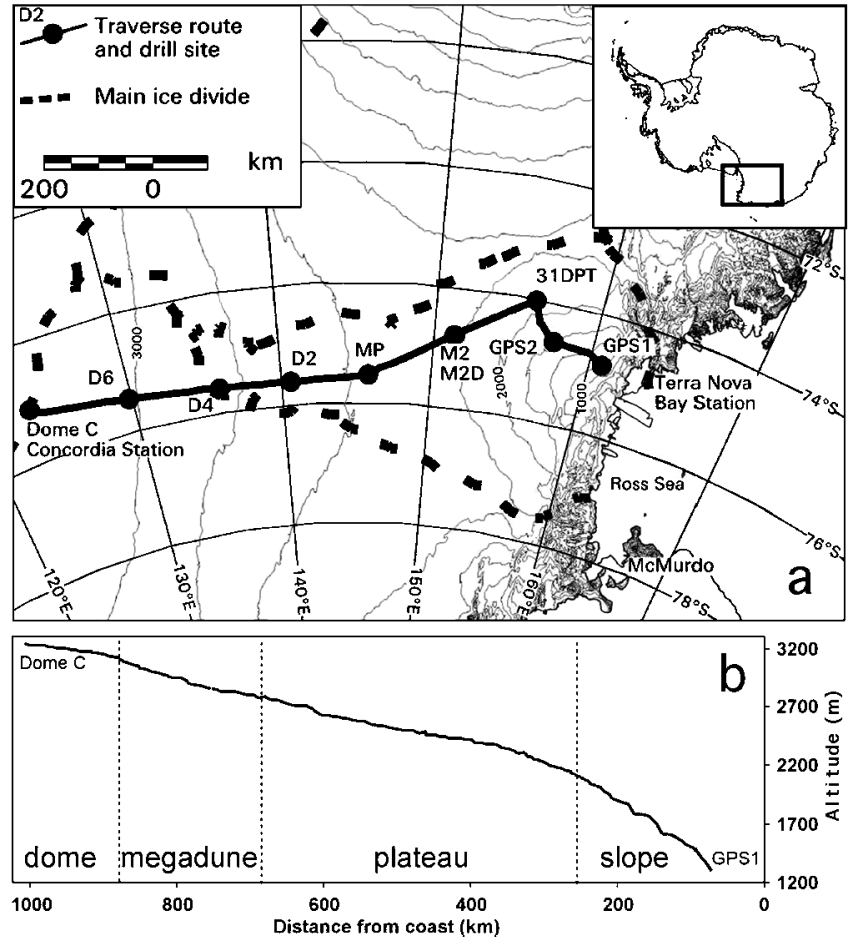

Fig. 1. (a) ITASE traverse route and main sample sites. (b) Topographic profile vs distance from coast.

$31 \%$, redistribution features (sastrugi) 59\% and depositional features only $10 \%$ of surface features. Wind crusts are present along the traverse where the slope is $>4 \mathrm{~m} \mathrm{~km}^{-1}$ (Frezzotti and others, 2002). Trenches cut along the traverse (M2 and M2D sites) in the presence of wind crust show the depth-hoar layer (up to $2 \mathrm{~m}$ deep), with a very coarse grain-size (up to $1 \mathrm{~mm}$ ). Under a strongly developed wind crust, the depth-hoar layer clearly indicates prolonged sublimation and upward transport of water vapour due to a hiatus in accumulation and therefore a long, multi-annual, steep temperature-gradient metamorphism (Gow, 1965; Fujii and Kusunoki, 1982).

\section{SITE DESGRIPTION}

Surface elevation profiles and local topography along the Terra Nova Bay-Dome $\mathrm{C}$ traverse were measured by global positioning system (Urbini and others, in press), whereas regional surface topography was analyzed using a digital elevation model of Antarctica with ground resolution of $1 \mathrm{~km}$, provided by Rémy and others (1999). The traverse crossed the entire basin of David Glacier, the largest outlet glacier in Victoria Land. It drains the inner part of the plateau flowing from eastern Dome C. The David Glacier catchment area ends $340 \mathrm{~km}$ short of the Dome C culmination (Frezzotti and others, 2000). The first $340 \mathrm{~km}$ of the eastern Dome C drainage area flows into the Ross Ice Shelf. For logistic requirements (crevassed areas and fuel deposits) the traverse did not follow a straight line between GPSl and Dome C (Fig. la).

The topographic profile of the traverse (Fig. 1b) indicates four sectors: the slope area between GPS1 and about $250 \mathrm{~km}$ from the coast has a slope value up to $2.5 \%$ and is characterized by redistribution (sastrugi) and erosional features (wind crusts); the plateau area from 250 to $680 \mathrm{~km}$ has a slope up to $0.45 \%$ and is characterized primarily by redistribution micro-relief and secondly by erosional features; the megadune area between 680 and $875 \mathrm{~km}$ has a steady value of $0.2-0.1 \%$; and the dome area from 875 to $1010 \mathrm{~km}$ has a slope of $<0.2 \%$ and is characterized by depositional features (Frezzotti and others, 2002). The slope profile shows very high variability along the slope and plateau area, and a homogeneous slope in the dome area (Fig. 1b). Snow accumulation decreases from the coastal area to the plateau, with values of $30-150 \mathrm{~kg} \mathrm{~m}^{-2} \mathrm{a}^{-1}$ (Giovinetto and Bentley, 1985).

\section{SAMPLING AND ANALYTIGAL METHODS}

Surface snow was sampled up to $1 \mathrm{~m}$ by a hand-operated driller, then sealed in polyethylene bags and kept frozen. These $1 \mathrm{~m}$ cores were cleaned by removing the outer part of the core with a stainless-steel scraper, then entirely melted and analyzed.

The snow pits were dug and the snow walls were cleaned by removing a $30-50 \mathrm{~cm}$ layer with a shovel, and a $10-15 \mathrm{~cm}$ layer with a stainless-steel scraper, before sampling. The sampling procedure is reported in Udisti and others (1999).

The shallow firn cores (10-50 $\mathrm{m}$ depth) were drilled using an electromechanical drilling system. Samples were stored in polyethylene bags under frozen conditions. After surface cleaning in a cold room, the shallow firn cores were sampled every $3-4 \mathrm{~cm}$.

The analyses of MSA, $\mathrm{Cl}^{-}, \mathrm{NO}_{3}{ }^{-}, \mathrm{SO}_{4}{ }^{2-}, \mathrm{Na}^{+}, \mathrm{K}^{+}, \mathrm{Mg}^{2+}$, $\mathrm{Ca}^{2+}$ were performed by ion chromatography, following the procedures reported in Gragnani and others (1998) and Udisti and others (1999). Stable-isotope analyses were performed following the procedures reported in Stenni and others (2002). Tritium analyses were carried out by liquid scintillation counting using a 1220 Quantulus apparatus after tritium enrichment obtained by electrolysis cells with stainless-steel electrodes from an initial weight of $250 \mathrm{~g}$ to a final weight of $20 \mathrm{~g}$. Tritium values are given in tritium units (TU) where $1 \mathrm{TU}$ corresponds to $\mathrm{T} / \mathrm{H}=10^{-18}$ calculated at the sampling date (November 1998-January 1999). Errors range from $1 \mathrm{TU}(2 \sigma)$ at the background level to $3 \mathrm{TU}$ at the level of $35 \mathrm{TU}$.

\section{RESULTS AND DISGUSSION}

\section{1. Snow pits and shallow firn cores}

Here we looked at depth/concentration profiles of $\mathrm{Cl}^{-}, \mathrm{NO}_{3}$ and methanesulphonate, because their acidic species $(\mathrm{HCl}$, $\mathrm{HNO}_{3}$ and MSA) are relatively volatile and their concentrations could be affected by movement in the snow layers and re-emission into the atmosphere, especially at stations with low accumulation rate $\left(<80 \mathrm{~kg} \mathrm{~m}^{-2} \mathrm{a}^{-1}\right.$ ) (Wolff, 1995, 1996; Legrand and others, 1996; Wagnon and others, 1999). Such post-depositional processes can change the original snow composition and are characterized by a decreasing trend in concentration from the surface to the deeper layers. Indeed, a different pattern of $\mathrm{Cl}^{-}, \mathrm{NO}_{3}{ }^{-}$and MSA is shown by Figure $2 \mathrm{a}-\mathrm{f}$. The uppermost snow layers of station M2 (pit M2 and core M2), located $327 \mathrm{~km}$ from the coast at $2308 \mathrm{~m}$ a.s.l. (Fig. la), are characterized by relatively high concentrations of $\mathrm{NO}_{3}{ }^{-}, \mathrm{nssCl}^{-}$and MSA (Fig. 2a and b), but their concentrations quickly decrease, reaching very low background values $\left(\mathrm{NO}_{3}{ }^{-}=0.2, \mathrm{nssCl}^{-} \cong 0.2\right.$ and $\mathrm{MSA}=$ $\left.0.01 \mu \mathrm{eq} \mathrm{L}^{-1}\right)$ in the sub-superficial layers. In contrast, no such dramatic decrease is visible in the M2D core (Fig. 2c) (average values: $\mathrm{NO}_{3}{ }^{-}=1.4, \mathrm{nssCl}^{-}=0.57$ and $\mathrm{MSA}=0.12 \mu \mathrm{eq}$ $\mathrm{L}^{-1}$ ), located only a few kilometres away (Table 1). The two stations have very different surface physical features: M2 is characterized by the presence of a wind crust and depth- 

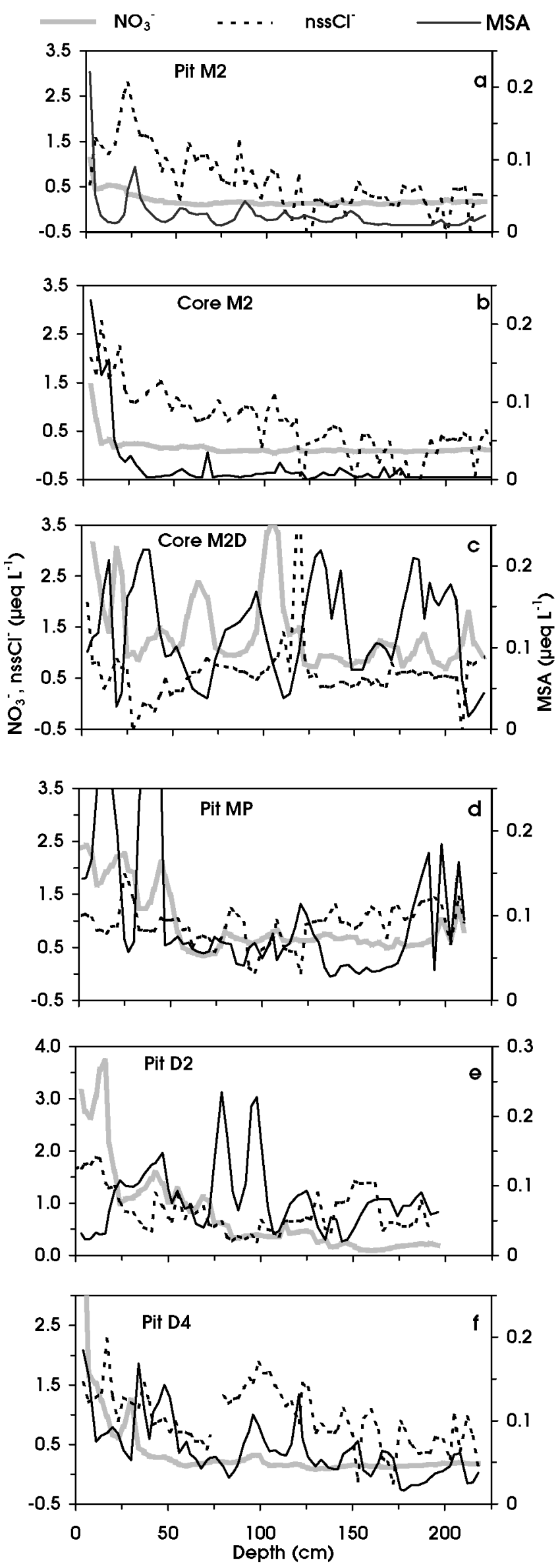

Fig. 2. Depth profiles of $\mathrm{NO}_{3}^{-}, n s s \mathrm{Cl}$ and MSA in pit M2 (a), core $M 2$ (b), core $M 2 D$ (c), pit MP (d), pit D2 (e) and pit $D 4(f)$.

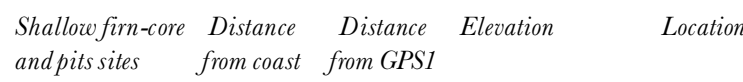

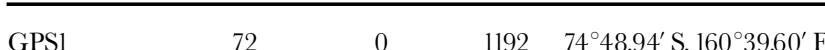

$\begin{array}{lllll}\text { GPS2 } & 167 & 97 & 1776 & 74^{\circ} 38.69^{\prime} \mathrm{S}, 157^{\circ} 30.13^{\prime} \mathrm{E}\end{array}$

$\begin{array}{lllll}31 \mathrm{DPT} & 238 & 181 & 2065 & 74^{\circ} 01.52^{\prime} \mathrm{S}, 155^{\circ} 57.06^{\prime} \mathrm{E}\end{array}$

M2* $327 \quad 344 \quad 2308 \quad 74^{\circ} 48.27^{\prime} \mathrm{S}, 151^{\circ} 16.17^{\prime} \mathrm{E}$

M2D* $\quad 330 \quad 349 \quad 2300 \quad 74^{\circ} 49.86^{\prime} \mathrm{S}, 151^{\circ} 09.13^{\prime} \mathrm{E}$

MP* $\quad 460 \quad 519 \quad 2454 \quad 75^{\circ} 32.16^{\prime} \mathrm{S}, 145^{\circ} 51.43^{\prime} \mathrm{E}$

$\begin{array}{lllll}\mathrm{D} 2 * & 587 & 662 & 2611 & 75^{\circ} 37.33^{\prime} \mathrm{S}, 140^{\circ} 37.84^{\prime} \mathrm{E}\end{array}$

D4* $\quad 692 \quad 794 \quad 2792 \quad 75^{\circ} 35.88^{\prime} \mathrm{S}, 135^{\circ} 49.89^{\prime} \mathrm{E}$

$\begin{array}{lllll}\text { D6 } & 851 & 961 & 3024 & 75^{\circ} 26.85^{\prime} \mathrm{S}, 129^{\circ} 48.53^{\prime} \mathrm{E}\end{array}$

DC (Dome C) $1012 \quad 1146 \quad 3232 \quad 75^{\circ} 07.32^{\prime} \mathrm{S}, 123^{\circ} 18.72^{\prime} \mathrm{E}$

*Data discussed in the present paper.

hoar layer (up to $2 \mathrm{~m}$ depth), while at M2D no wind crusts were found. At increasing distance from the coastline, at MP and D2 pits (located 460 and $586 \mathrm{~km}$, respectively, from the coast), chemical profiles show a sharp decrease with depth only for $\mathrm{NO}_{3}{ }^{-}$(Fig. 2d and e). Finally, at D4 station (plateau area) the profiles show a clear decreasing trend for $\mathrm{NO}_{3}$ and $\mathrm{nssCl}^{-}$(Fig. 2f). Therefore, along the PNRA-ITASE traverse, such a perturbation of superficial layers shows a progressive pattern as distance from the sea increases, with a higher sensitivity for $\mathrm{NO}_{3}^{-}$. Post-depositional losses of gaseous $\mathrm{HNO}_{3}$ and $\mathrm{HCl}$ have been observed at many central Antarctic sites and attributed to the low-accumulation-rate effects (e.g. De Angelis and Legrand, 1995; Dibb and Whitlow, 1996; Wagnon and others, 1999). Indeed, we observed $\mathrm{Cl}^{-}$and $\mathrm{NO}_{3}{ }^{-}$decreasing in stations with accumulation rates $<50 \mathrm{~kg} \mathrm{~m}^{-2} \mathrm{a}^{-1}$ (MP and D4) (Giovinetto and Bentley, 1985), or characterized by wind ablation processes, which can give rise to a long hiatus in accumulation (M2). Moreover, the concentration decreasing with depth shown by the MSA profile at M2 station (Fig. 2a and b) is similar to that found at Vostok (Wagnon and others, 1999), where the snow-accumulation rate is only about $20 \mathrm{~kg} \mathrm{~m}^{-2} \mathrm{a}^{-1}$ (Jouzel and others, 1993). To explain this finding, Wagnon and others (1999) suggested possible re-emission into the atmosphere by a significant contribution of MSA in gas phase.

Although the mechanisms involved in the post-depositional processes are not yet satisfactorily understood (De Angelis and Legrand, 1995; Wolff, 1996), the multi-annual steep temperature-gradient metamorphism (due to wind scouring and/or small precipitation) seems to be a powerful discriminating parameter for all three examined compounds. ITASE stations confirm that re-emissions of $\mathrm{HNO}_{3}$, $\mathrm{HCl}$ and MSA into the atmosphere can heavily affect the preservation in the snow of these potentially relevant environmental and climatic markers.

\subsection{Surface snow}

\subsubsection{Stable isotope}

The $\delta^{18} \mathrm{O}$ values obtained from 227 surface snow samples $(1 \mathrm{~m}$ cores) are presented in Figure $3 \mathrm{a}$ as a function of distance from the coast. A decreasing trend may be observed, with more $\delta^{18} \mathrm{O}$ depleted values occurring inland and at higher elevation, which is the result of temperature decrease with increasing altitude. An elevation gradient of $-1 \%_{0}(100 \mathrm{~m})^{-1}$ has been calculated for the whole traverse. The $\delta^{18} \mathrm{O}$ values of the traverse exhibit high spatial variability, with a larger 

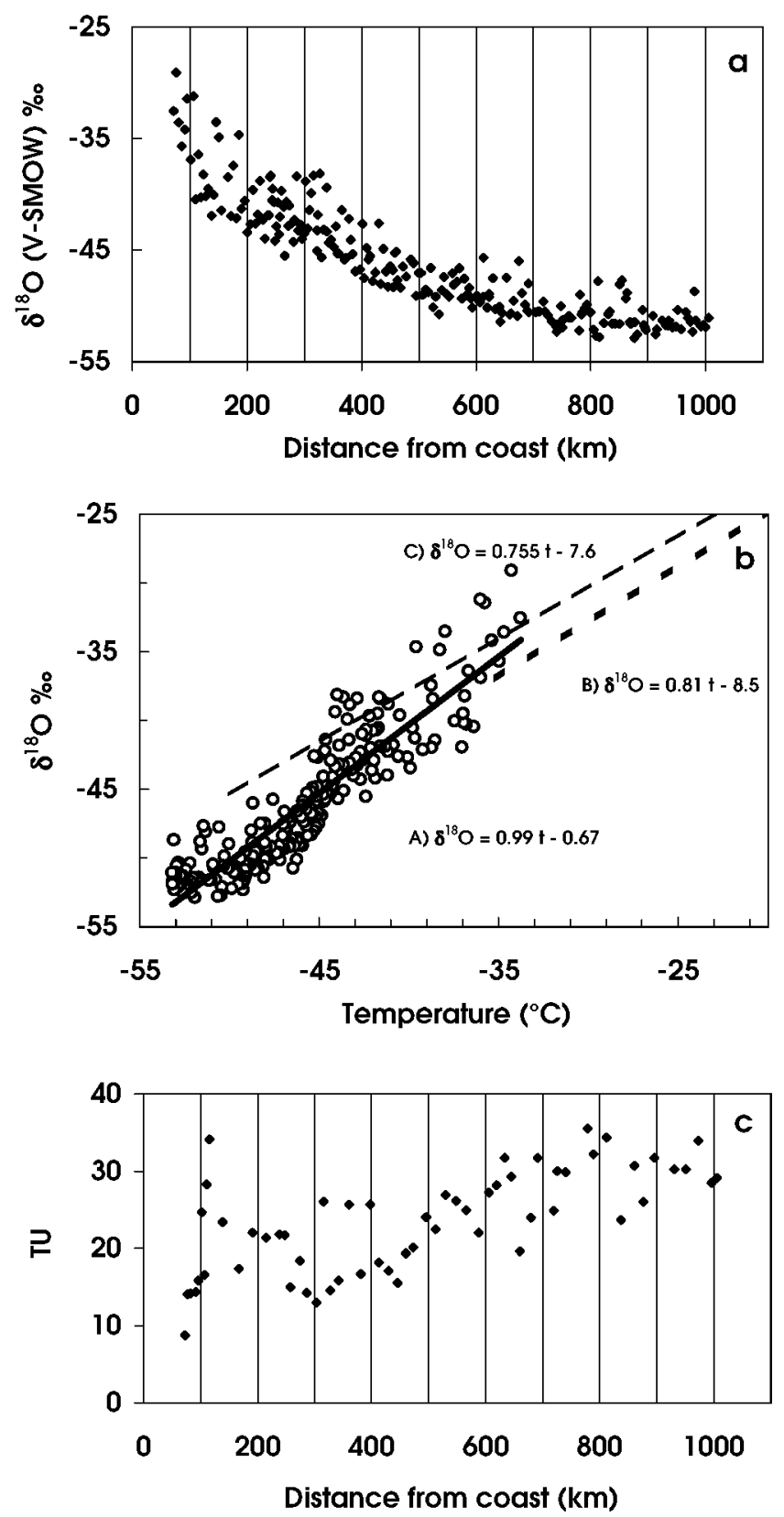

Fig. 3. $\delta^{18} O(a)$ and tritium (c) values in surface snow vs distance from coast. (b) $\delta^{18} \mathrm{O} / \mathrm{T}$ : solid line (A) shows the least-squares regression between $\delta^{18} O$ and temperature for surface snow (open circles) along the ITASE traverse; dotted line $(B)$ shows the northern Victoria Land regression (Stenni and others, 2000); and dashed line ( $C$ ) shows the Terre Adélie regression (Lorius and Merlivat, 1977).

scattering observed in the first part of the traverse up to $350 \mathrm{~km}$ from the coast; on the other hand, $\delta^{18} \mathrm{O}$ values from $750 \mathrm{~km}$ to Dome C exhibit more or less constant values. This distribution pattern may be related to the different topography encountered along the traverse. The first part is characterized by steeper slopes with redistribution and erosional aeolian features, and therefore more affected by wind scouring; while on the plateau the slope decreases and is characterized by redistribution and depositional aeolian features.

Linear relationships between $\delta^{18} \mathrm{O}$ and mean annual surface temperatures $(T)$ at sampling sites have been reported for different Antarctic regions (Lorius and Merlivat, 1977; Qin and others, 1994). In general, the geographical dependence of this spatially derived relationship relies mainly on differences in the climatological situations and in the mois- ture-source regions supplying the precipitation over different parts of Antarctica. The spatial $\delta^{18} \mathrm{O} / T$ relationship obtained in this study is presented in Figure $3 \mathrm{~b}$. The surface temperatures used to reconstruct the least-squares regression have been calculated interpolating the available temperatures as measured at $15 \mathrm{~m}$ in the core, and elevation along the traverse (Frezzotti and Flora, in press). A good correlation $\left(R^{2}=0.83\right.$ ) is observed between $\delta^{18} \mathrm{O}$ values and site temperatures for this dataset, with a $\delta^{18} \mathrm{O} / T$ gradient of $0.99 \%{ }^{\circ} \mathrm{C}^{-1}$. This value is higher than the Lorius and Merlivat (1977) gradient of $0.75 \%{ }^{\circ} \mathrm{C}^{-1}$ found in the region from Dumont d'Urville to Dome $\mathrm{G}$ in Terre Adélie and is commonly used in East Antarctica for palaeotemperature reconstruction. The Lorius and Merlivat (1977) equation and that obtained in northern Victoria Land for more coastal sites (Stenni and others, 2000) are also reported in Figure 3b for comparison. The observed difference among these regression lines could be related to different oceanic source regions delivering moisture to the continent. Recently, Delaygue and others (2000) have used an atmospheric general circulation model to show that most of the moisture that precipitates in Antarctica originates in the subtropical and mid-latitude regions, with moisture from the proximal ocean basin influencing a given region.

\subsubsection{Tritium}

The preliminary results obtained from the tritium analyses of the surface samples ( $1 \mathrm{~m}$ cores) collected along the traverse are presented in Figure 3c. The tritium trend is in agreement with those observed in Antarctica before emission into the atmosphere of artificial tritium produced by the thermonuclear bomb tests (1952-68) that arrived in Antarctica after a 2 year delay (Jouzel and others, 1979).

Except for a few anomalous values between GPS1 and GPS2, a positive trend is observed in the tritium activity moving inland and with higher elevation. These variations are mainly related to changes in both elevation and distance from the coast, being the route of the traverse nearly parallel to $75^{\circ} \mathrm{S}$ of latitude. The observed increase may be due to a more efficient winter exchange between stratosphere and troposphere at higher elevations. However, changes in the accumulation rate occurring at different sampling sites cannot be discounted. A positive correlation between tritium activity and elevation has been observed previously in Antarctica by Merlivat and others (1977), while Jouzel and others (1979) reported an increase of tritium values with increasing distance from the coast.

\subsubsection{Primary aerosol}

Primary aerosol components, essentially comprising windborne sea salt $\left(\mathrm{Na}^{+}, \mathrm{Cl}^{-}, \mathrm{Mg}^{2+}\right.$ and partially $\left.\mathrm{SO}_{4}{ }^{2-}\right)$ and crustal $\left(\mathrm{Ca}^{2+}\right.$ and $\left.\mathrm{K}^{+}\right)$sources, show the highest spatial variability, with a general and fast decrease as the altitude and distance from the sea increases. Figure $4 \mathrm{a}-\mathrm{c}$ show the inland traverse profiles of $\mathrm{Na}^{+}, \mathrm{Cl}^{-}$and $\mathrm{Mg}^{2+}$, which are all very similar. In the $70-250 \mathrm{~km}$ range, their concentration quickly decreases from the high values measured near the coast to values about 10 times lower, following an exponential pattern. This progressive pattern is heavily modulated by spikes and abrupt, in-phase, oscillations of all three components, probably due to salt-storm events which are more frequent in the winter periods (Udisti and others, 1999; Stenni and others, 2000). From 270 to $1000 \mathrm{~km}$, all three elements show relatively constant background values, with very low-intensity spikes. 

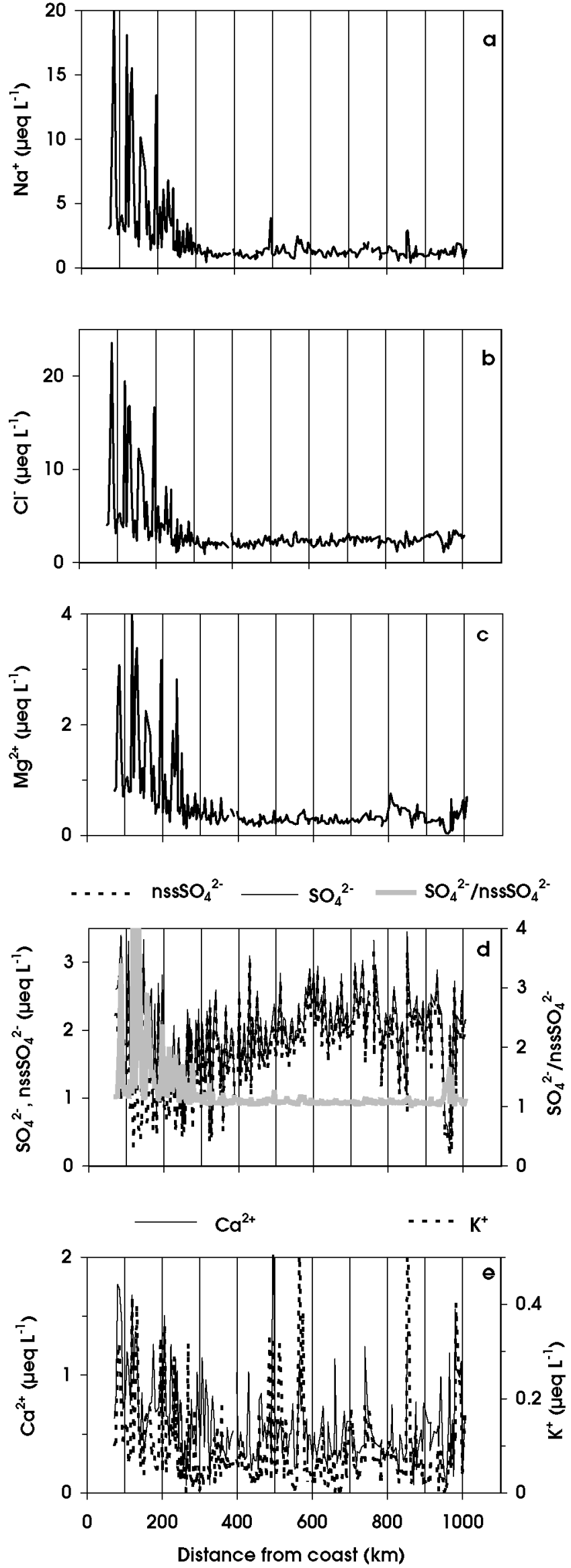

Fig. 4. $\mathrm{Na}^{+}(\mathrm{a}), \mathrm{Cl}$ (b), $\mathrm{Mg}^{2+}$ (c), $\mathrm{SO}_{4}^{2}, \mathrm{nsSO}_{4}^{2}$ and $\mathrm{SO}_{4}^{2} /$ nsSO $_{4}^{2}(d)$, and $\mathrm{Ca}^{2+}$ and $\mathrm{K}^{+}(e)$ concentrations in surface snow vs distance from coast.

As seen in Figure 1b, the first distance range shows the highest altitude gradient, with an altitude increase of about $1000 \mathrm{~m}$ (from 1200 to $2200 \mathrm{~m}$ a.s.l.) in the first $180 \mathrm{~km}$. The next $1000 \mathrm{~m}$ elevation increase (up to $3200 \mathrm{~m}$ a.s.l. at Dome C) is achieved along $800 \mathrm{~km}$, with a gradient 4.5 times lower. As distance from the coast and altitude contemporaneously increase, it is impossible to assess which is the crucial parameter in determining the penetration of these compounds inland on the Antarctic ice sheet. Mulvaney and Wolff (1994) and Kreutz and Mayewski (1999) found that altitude is a more significant parameter than distance from the coast. Measurements carried out at the coastal site of northern Victoria Land (Udisti and others, 1999) confirmed the dominant effect of altitude on the scavenging processes of primary marine aerosol in the first $1500 \mathrm{~m}$ a.s.l. Therefore, from the transect data, the distance of $270 \mathrm{~km}$ from the coast, i.e. at altitudes of about $2000 \mathrm{~m}$ a.s.l., could be considered as a boundary area for the transport of primary marine aerosol. Beyond this area, the concentration of sea-salt components shows more constant levels (plateau background values).

The total $\mathrm{SO}_{4}{ }^{2-}$ traverse profile (Fig. $4 \mathrm{~d}$ ) shows a more complex pattern than the wind-borne sea-salt compounds. Like $\mathrm{Na}^{+}, \mathrm{Cl}^{-}$and $\mathrm{Mg}^{2+}$, in the $70-270 \mathrm{~km}$ range, $\mathrm{SO}_{4}{ }^{2-}$ concentration shows a decreasing trend modulated by several spikes. Minimum values, about five times lower than coastal levels, are measured at about $250 \mathrm{~km}$ from the coast. Beyond $270 \mathrm{~km}$, the $\mathrm{SO}_{4}{ }^{2-}$ concentration progressively increases to about $2.3 \mu \mathrm{eq} \mathrm{L}^{-1}$ in the range $550-750 \mathrm{~km}$ from the coast. For the farthest sites, the concentration levels show large fluctuations around mean values of about $2 \mu \mathrm{eq} \mathrm{L}^{-1}$, with an absolute minimum at about $940 \mathrm{~km}$ from the coast. Many other compounds, such as $\mathrm{Cl}^{-}, \mathrm{Mg}^{2+}, \mathrm{Ca}^{2+}, \mathrm{NO}_{3}{ }^{-}$and MSA, show minimum values at this distance (Figs $4 \mathrm{~b}, \mathrm{c}$ and e and $5 \mathrm{c}$ and $\mathrm{d}$ ). Unlike the sea-salt markers, $\mathrm{SO}_{4}{ }^{2-}$ shows several spikes regularly distributed all along the traverse. $\mathrm{The} \mathrm{SO}_{4}{ }^{2-}$ trend is mainly driven by changes in the relative importance of the two main contributions: wind-borne sea salt and marine biogenic sources. In the first step $(70-270 \mathrm{~km})$, wind-borne seasalt contribution is dominant and so the $\mathrm{SO}_{4}{ }^{2-}$ profile is similar to those of $\mathrm{Na}^{+}, \mathrm{Cl}^{-}$and $\mathrm{Mg}^{2+}$ (Fig. $4 \mathrm{a}^{-} \mathrm{C}$ ). As distance increases, the secondary contributor $\left(\mathrm{nssSO}_{4}{ }^{2-}\right.$ from oxidation of dimethylsulphide (DMS) emitted by phytoplanktonic activity) becomes more and more important (Fig. 4d), because the diameter of the related aerosol particles is shifted toward the finest size fraction, and the secondary aerosol is mainly affected by long-range atmospheric transport (Saltzman and others, 1983, 1986; Pszenny and others, 1989).

The high variability of the $\mathrm{SO}_{4}{ }^{2-}$ concentration at the plateau sites could be related to wind scouring at the different sampling stations. Snow accumulation generally decreases with altitude and distance from the coast, but the local topographic condition (slope) drives the wind scouring and therefore redistribution and ablation processes (Frezzotti and others, 2002).

Figure $4 \mathrm{e}$ shows the spatial profiles of $\mathrm{Ca}^{2+}$ and $\mathrm{K}^{+}$. These components arise from two main sources: crustal and marine primary aerosol (Legrand and others, 1988). As with total $\mathrm{SO}_{4}{ }^{2-}$, the sea-salt fraction is dominant in the first distance range $(70-270 \mathrm{~km})$, where a pattern very similar to that of $\mathrm{Na}^{+}$is evident. A concentration decrease occurs in this range, where $\mathrm{Ca}^{2+}$ and $\mathrm{K}^{+}$concentrations reach minimum values, about 5-10 times lower than the values measured at the sites nearest to the coast. Beyond $270 \mathrm{~km}$, the background level remains relatively constant around values of 0.4 and $0.03 \mu \mathrm{eq} \mathrm{L}^{-1}$ for $\mathrm{Ca}^{2+}$ and $\mathrm{K}^{+}$, respectively. Unlike sea-salt compounds, these background values are heavily modulated by high spikes, probably 

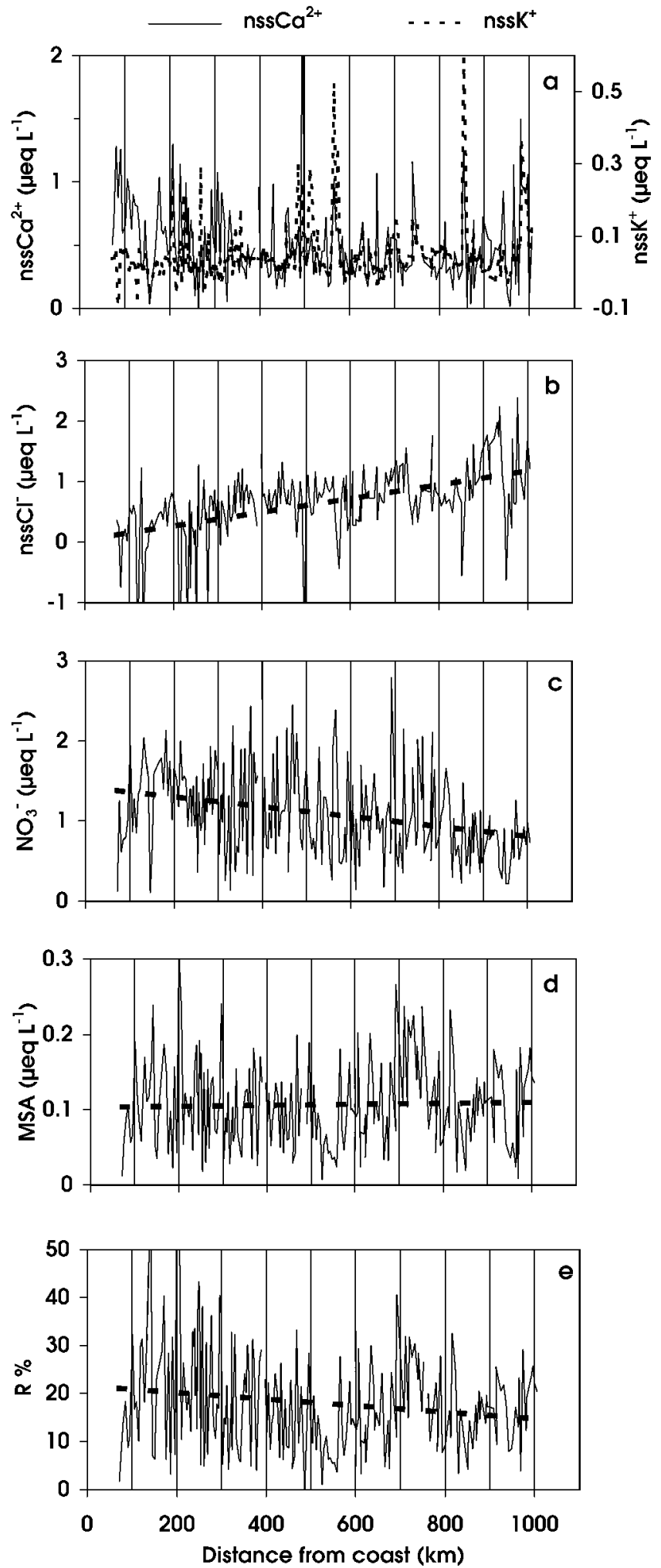

Fig. 5. $n s s \mathrm{Ca}^{2+}$ and $n s s K^{+}$(a), nssCl (b), $\mathrm{NO}_{3}^{-}$(c) and $M S A(d)$ concentrations, and $R \%$ ( $M S A / M S A+$ $\left.\left.n s S^{2}{ }_{4}^{2}\right) \times 100\right)(e)$ values, in surface snow vs distance from coast. The dashed line shows the linear regression.

caused by dust depositions from intrusion of air masses transporting continental aerosols. Peaks in both profiles are particularly evident at the sites located at about 500, $570,740,850$ and $980 \mathrm{~km}$ from coast. $\mathrm{Ca}^{2+}$ and $\mathrm{K}^{+}$peaks are not perfectly in phase with each other, and the relative heights are different, but they are located at the same distance from the sea.

To evaluate crustal contributions, we calculate the nonsea-salt concentrations for $\mathrm{Ca}^{2+}$ and $\mathrm{K}^{+}$. The $\mathrm{nssCa}^{2+}$ profile shows a decreasing trend, less evident than that of total $\mathrm{Ca}^{2+}$, between 70 and $330 \mathrm{~km}$. Beyond $330 \mathrm{~km}$, the background values are highly modulated by several spikes along the whole profile. This pattern suggests a crustal contribution from the coastal area which decreases inland, with sporadic dust deposition on the plateau area. In contrast, $\mathrm{nssK}^{+}$concentration does not show a decrease in the first distance range (Fig. 5a), so the crustal source appears to be less important for this component. Also, the $\mathrm{nssK}^{+}$profile is modulated by some peaks. As such spikes are generally in phase with $\mathrm{nssCa}^{2+}$ peaks, similar transport mechanisms may be proposed.

\subsubsection{Secondary aerosol}

The nss $\mathrm{Cl}^{-}$concentration along the traverse shows a progressive increase as distance increases (Fig. 5b). This pattern is due to the progressively higher relevance of secondary contributions to the $\mathrm{Cl}^{-}$budget. A similar trend is shown in the International Trans-Antarctic Expedition (ITAE) profile (Qin, 1995). A nss $\mathrm{Cl}^{-}$concentration increase is observed in the traverse route from Mirny to Vostok, where the accumulation rate is particularly low. Beyond Vostok, $\mathrm{nssCl}^{-}$concentration progressively decreases as accumulation rate increases.

The $\mathrm{NO}_{3}{ }^{-}$concentration shows a very irregular profile, with a decreasing trend as altitude increases (Fig. 5c). This distribution could be related to natural variability with different contributions of the various $\mathrm{NO}_{3}{ }^{-}$sources (Zeller and Parker, 1981; Parker and others, 1982; Legrand and Kirchner, 1990; Qin and others, 1992). Although in Antarctica the main sources of $\mathrm{NO}_{x}$ are downward transport from stratosphere/troposphere and long-range transport of $\mathrm{NO}_{\bar{x}}$ enriched air masses by tropical lightning (Legrand and Kirchner, 1990), other sources can increase the variability of the $\mathrm{NO}_{3}{ }^{-}$content, by dry and snow deposition, such as biogenic activity and nitrate-organic compounds, further complicating the interpretation of the global balance of the atmospheric $\mathrm{NO}_{3}{ }^{-}$budget (Dibb and others, 1998; Jones and others, 1999). In addition, post-depositional modifications, mainly related to re-emission of $\mathrm{HNO}_{3}$ into the atmosphere, occur at sites characterized by wind scouring and low accumulation rate. $\mathrm{NO}_{3}{ }^{-}$loss has been found at stations M2, MP, D2 and D4 (Fig. 2a, d, e and f).

As shown by the linear regression in Figure $5 \mathrm{c}$, the $\mathrm{NO}_{3}{ }^{-}$ traverse profile shows a decreasing trend as distance from the coast increases. This pattern is opposite to that expected for components related to secondary aerosol, as shown by the nss $\mathrm{Cl}^{-}$profile (Fig. 5b). The lower $\mathrm{NO}_{3}{ }^{-}$concentrations observed in inland stations are in agreement with $\mathrm{NO}_{3}{ }^{-}$ post-depositional re-emission occurring at low-accumulation sites (Traversi and others, 2000). In fact, $\mathrm{NO}_{3}{ }^{-}$dips are observed at sites characterized by low accumulation rates caused by low snow precipitation or by wind ablation (e.g. at 151, 327, 612 and $672 \mathrm{~km}$ from the coast). The relationship between altitude, or distance from the sea, and $\mathrm{NO}_{3}{ }^{-}$concentration is not clear: some authors refer to a positive altitude/ concentration correlation (Mulvaney and Wolff, 1994), while others report no relationship with elevation (Kreutz and Mayewski, 1999), highlighting a still limited understanding regarding $\mathrm{NO}_{3}{ }^{-}$deposition and post-depositional effects.

Along the traverse, $\mathrm{nssSO}_{4}{ }^{2-}$ concentration shows a slight decrease up to about $250 \mathrm{~km}$ from the coast, but this decrease is much lower than that observed for the total $\mathrm{SO}_{4}{ }^{2-}$ profile (Fig. 4d). From 270 to $600 \mathrm{~km}$ inland, the con- 
centration increases with a progressive trend, modulated by many spikes. In the distance range $600-900 \mathrm{~km}$, steadily higher values are observed. Finally, around $940 \mathrm{~km}$, an abrupt and deep decrease is shown, like those of $\mathrm{Cl}^{-}, \mathrm{Ca}^{2+}$, $\mathrm{NO}_{3}{ }^{-}$and MSA (Figs $4 \mathrm{~b}$ and e and $5 \mathrm{c}$ and d). The slight $\mathrm{nssSO}_{4}{ }^{2-}$ decreasing trend in the first $250 \mathrm{~km}$ step suggests a fast deposition of primary aerosol. Because the sea-salt contribution was already subtracted, we suppose a progressive scavenging of crustal contributions. The lower rate of decrease, with respect to the sea-salt markers, could be explained by the lower contribution of dust to the primary atmospheric aerosol budget. $\mathrm{nss}_{4} \mathrm{SO}_{4}{ }^{2-}$ that originated from secondary sources and is related to the finest size fraction of the aerosol particles penetrates to the plateau areas reaching the Antarctic central ice sheet. The progressive increase of this fraction of sulphuric aerosol could be explained as a direct effect of the decreasing accumulation rate. This hypothesis is not supported by previous studies (Mulvaney and Wolff, 1994; Kreutz and Mayewski, 1999). These authors showed the $\mathrm{nsSSO}_{4}{ }^{2-}$ concentration is not positively correlated to accumulation rate, and supposed that $\mathrm{nssSO}_{4}{ }^{2-}$ and distance inland are independent of each other or negatively correlated. Nevertheless, along the ITAE traverse (Qin, 1995) between Mirny and Vostok, the variation of the nss $\mathrm{SO}_{4}{ }^{2-}$ concentrations vs inland distance shows a trend similar to that found in the present study.

The MSA traverse profile (Fig. 5d) shows a high variability, with a large peak at $730 \mathrm{~km}$ and two deep troughs at 550 and $965 \mathrm{~km}$. The last feature is present in all analytical profiles, and this pattern could be related to local conditions. The trough at $550 \mathrm{~km}$ and the peak at $730 \mathrm{~km}$ are out of phase with respect to troughs and peaks found in the profiles of the other compounds. The mean MSA value along the whole traverse is $0.11 \mu \mathrm{eq} \mathrm{L}^{-1}$, with a standard deviation of $0.06 \mu \mathrm{eq} \mathrm{L}^{-1}$. These values are similar to those found in surface snow of the Antarctic ice sheet by Qin (1995), along the route of the 1990 ITAE, and to the data reported by Kreutz and Mayewski (1999) for surface snow measured in different Antarctic stations. Due to its biogenic marine origin, MSA concentration is expected to decrease with distance inland and increasing altitude (Legrand and others, 1992; Udisti and others, 1998; Kreutz and Mayewski, 1999). On the other hand, MSA is acting as cloud condensation nuclei and is distributed in the finest size fraction of the aerosol particles (Saltzman and others, 1983, 1986; Pszenny and others, 1989); in such a way MSA, like the finest fraction of $\mathrm{nss} \mathrm{SO}_{4}{ }^{2-}$, is carried out more efficiently over the Antarctic plateau. The large contribution to the MSA budget coming from longrange transport of air masses originating at low latitudes (Saigne and Legrand, 1987) supports this hypothesis.

The patterns observed in the MSA profile could be caused by two opposing effects: as distance from the sea increases, the oceanic source contribution becomes progressively lower, causing lower concentration in snow; in contrast, the decrease in mean accumulation rate leads to higher concentrations in snowfall.

The MSA fraction $\left(R=\mathrm{MSA} / \mathrm{MSA}+\mathrm{nsSSO}_{4}{ }^{2-}\right)$ plotted vs distance shows a high variability. The highest values are observed in the first $300 \mathrm{~km}$ inland (Fig. 5e). In the Southern Ocean atmosphere, $R$ values are negatively correlated with air temperature (Berresheim, 1987; Bates and others, 1992) because the distribution between MSA and $\mathrm{nsSSO}_{4}{ }^{2-}$ during the DMS oxidation yields a greater $\mathrm{SO}_{2}$ percentage at relatively higher temperatures. If $R$ is representative of the air-mass origin, it could be used as a marker to distinguish between high- and low-latitude sources. In this way, $R$ values observed in the first part of the ITASE traverse and in the coastal Antarctic snow are in agreement with higher $R$ values found at high southern latitudes (Saigne and Legrand, 1987; Legrand and others, 1992; Udisti and others, 1998). The lower $R$ values observed in snow at higher plateau stations are mainly related to long-range transport from temperate latitudes. Nevertheless, due to the different size distribution of MSA and nssSO ${ }_{4}{ }^{2-}$ (Pszenny, 1992; Kerminen and others, 1998), fractionation phenomena can complicate the interpretation of $R$ values.

\section{GONGLUSIONS}

In this work we have presented the results of chemical and isotopic analysis of samples collected along a traverse, performed in 1998/99, from Terra Nova Bay to Dome C, in the framework of the ITASE project. Surface snow chemistry showed a high spatial variability due to changes in aerosol composition, wind scouring effects and firnification processes on both regional and local scales. In spite of this variability, the chemical analyses showed some remarkable features.

Sea-salt components $\left(\mathrm{Na}^{+}, \mathrm{Cl}^{-}\right.$and $\left.\mathrm{Mg}^{2+}\right)$ show a very similar trend in the traverse profile from the coastal to inland areas. In particular, their concentration decreases up to 10 times in the first $250 \mathrm{~km}$ inland, corresponding to the highest surface gradient. This confirms the importance of the surface altitude and distance from the coast in affecting the aerosol penetration inland on the Antarctic ice sheet. With regard to $\mathrm{nssCa}^{2+}$, both coastal and long-range dust inputs were found.

Post-depositional losses of $\mathrm{NO}_{3}{ }^{-}$, by re-emission of $\mathrm{HNO}_{3}$ into the atmosphere, were indicated in areas characterized by wind ablation or low snow-accumulation rate. With regard to $\mathrm{nss} \mathrm{Cl}^{-}$, a dramatic decrease with depth was observed at station M2 and pit D4; this pattern could also be explained by a post-depositional $\mathrm{HCl}$ re-emission into the atmosphere.

The $\mathrm{SO}_{4}{ }^{2-}$ profile is driven by sea-salt contribution in the first part $(70-270 \mathrm{~km})$ of the traverse. For greater distances, most of the $\mathrm{SO}_{4}{ }^{2-}$ budget is represented by $\mathrm{nssSO}_{4}{ }^{2-}$.

MSA concentration shows high variability along the traverse, due to two effects: the biogenic marine origin and accumulation-rate dilution effect. A possible MSA re-emission was observed at station M2, where strong wind scouring is present.

The calculated $\delta^{18} \mathrm{O}$-temperature gradient for the traverse is $0.99 \%{ }^{\circ} \mathrm{C}^{-1}$. The difference with the value obtained for Terre Adélie (Lorius and Merlivat, 1977) suggests different oceanic source regions for the moisture delivering the precipitation to these two areas.

To improve our knowledge of components distribution over the Antarctic ice sheet, further studies are required. Data from traverse expeditions represent the most useful tools to investigate several complex and still unexplained processes acting during and after snow deposition.

\section{ACKNOWLEDGEMENTS}

This research was carried out within the framework of a project on glaciology and palaeoclimatology of the PNRA and was financially supported by Ente per le Nuove Tecnologie, l'Energia e l'Ambiente (ENEA) through a cooperation agreement with the Università degli Studi di Milano Bicocca. This 
work is a contribution of the Italian branch of the ITASE project. It is an associate programme of the "European Project for Ice Coring in Antarctica" (EPICA), a joint European Science Foundation/European Commission scientific programme. The authors wish to thank all members of the traverse team, the participants in PNRA 1998/99 who assisted at the Terra Nova and Concordia stations and all persons in Italy who were involved in the preparation of the traverse. We are very grateful for the anonymous reviewer's comments on an earlier version of the manuscript.

\section{REFERENGES}

Bates, T. S., J. A. Calhoun and P. K. Quinn. 1992. Variations in the methanesulfonate to sulfate molar ratio in submicrometer marine aerosol particles over the south Pacific Ocean. F. Geophys. Res., 97(D9), 9859-9865.

Berresheim, H. 1987. Biogenic sulfur emission from the sub-Antarctic and Antarctic oceans. 7. Geophys. Res., 92(D11), 13,245-13,262.

De Angelis, M. and M. Legrand. 1995. Preliminary investigations of post depositional effects of $\mathrm{HCl}, \mathrm{HNO}_{3}$, and organic acids in polar firn layers. In Delmas, R. J., ed. Ice core studies of global biogeochemical cycles. Berlin, etc., Springer-Verlag, 361-381. (NATO ASI Series I: Global Environmental Change 30.)

Delaygue, G., V. Masson, J. Jouzel, R. D. Koster and R. Healy. 2000. The origin of Antarctic precipitation: a modelling approach. Tellus, 52B(1), 19-36.

Dibb, J. E. and S. I. Whitlow. 1996. Recent climate anomalies and their impact on snow chemistry at South Pole, 1987-1994. Geophys. Res. Lett., 23(10), 1115-1118.

Dibb, J. E., R. W. Talbot, J.W. Munger, D. J. Jacob and S. M. Fan. 1998. Airsnow exchange of $\mathrm{HNO}_{3}$ and $\mathrm{NO}_{y}$ at Summit, Greenland. 7. Geophys. Res., 103(D3), 3475-3486.

Frezzotti, M. and O. Flora. In press. Environmental and surface conditions along Terra Nova-Dome $\mathrm{C}$ traverse (East Antarctica): preliminary report. Terra Antartica.

Frezzotti, M., I. E. Tabacco and A. Zirizzotti. 2000. Ice discharge of eastern Dome C drainage area, Antarctica, determined from airborne radar survey and satellite image analysis. f. Glaciol., 46(153), 253-264.

Frezzotti, M., S. Gandolfi, F. La Marca and S. Urbini. 2002. Snow dunes and glazed surfaces in Antarctica: new field and remote-sensing data. Ann. Glaciol., 34, 81-88.

Fujii,Y. and K. Kusunoki. 1982. The role of sublimation and condensation in the formation of ice sheet surface at Mizuho Station, Antarctica. F. Geophys. Res., 87(C6), 4293-4300.

Giovinetto, M. B. and C. R. Bentley. 1985. Surface balance in ice drainage systems of Antarctica. Antarct. F. U.S., 20 (4), 6-13.

Goodwin, I. D. 1990. Snow accumulation and surface topography in the katabatic zone of eastern Wilkes Land, Antarctica. Antarct. Sci., 2(3), 235-242.

Gow, A. J. 1965. On the accumulation and seasonal stratification of snow at the South Pole. F. Glaciol., 5(40), 467-477.

Gragnani, R., C. Smiraglia, B. Stenni and S. Torcini. 1998. Chemical and isotopic profiles from snow pits and shallow firn cores on Campbell Glacier, northern Victoria Land, Antarctica. Ann. Glaciol., 27, 679-684.

Jones, A. E. and 8 others. 1999. Oxidized nitrogen chemistry and speciation in the Antarctic troposphere. F. Geophys. Res., 104(D17), 21,355-21,366.

Jouzel, J., L. Merlivat, M. Pourchet and C. Lorius. 1979. A continuous record of artificial tritium fallout at the South Pole (1954-1978). Earth Planet. Sci. Lett., 45(1), 188-200.

Jouzel, J. and 16 others. 1993. Extending the Vostok ice-core record of palaeoclimate to the penultimate glacial period. Nature, 364(6436), 407-411.

Kerminen, V.-M., R. E. Hillamo and A. S. Wexler. 1998. Model simulations on the variability of particulate MSA to non-sea-salt sulfate ratio in the marine environment. 7. Atmos. Chem., 30(3), 345-370.

Kreutz, K. J. and P. A. Mayewski. 1999. Spatial variability of Antarctic surface snow glaciochemistry: implications for paleoatmospheric circulation reconstructions. Antarct. Sci., 11 (1), 105-118.

Legrand, M. R. and S. Kirchner. 1990. Origins and variations of nitrate in south polar precipitation. 7. Geophys. Res., 95(D4), 3493-3507.

Legrand, M. R., C. Lorius, N. I. Barkov and V. N. Petrov. 1988. Vostok (Antarctica) ice core: atmospheric chemistry changes over the last climatic cycle (160,000 years). Atmos. Environ., 22(2), 317-331.

Legrand, M., C. Feniet-Saigne, E. S. Saltzman and C. Germain. 1992. Spatial and temporal variations of methanesulfonic acid and non sea salt sulfate in Antarctic ice. 7. Atmos. Chem., 14(1-4), 245-260.

Legrand, M., A. Léopold and F. Dominé. 1996. Acidic gases (HCl, HF, $\mathrm{HNO}_{3}, \mathrm{HCOOH}$, and $\mathrm{CH}_{3} \mathrm{COOH}$ ): a review of ice core data and some preliminary discussions on their air-snow relationships. In Wolff, E.W. and R. C. Bales, eds. Chemical exchange between the atmosphere and polar snow. Berlin, etc., Springer-Verlag, 19-43. (NATO ASI Series I: Global Environmental Change 43.)

Lorius, C. and L. Merlivat. 1977. Distribution of mean surface stable isotope values in East Antarctica: observed changes with depth in the coastal area. International Association of Hydrological Sciences Publication 118 (Symposium at Grenoble 1975 - Isotopes and Impurities in Snow and Ice ), 127-137.

Merlivat, L., J. Jouzel, J. Robert and C. Lorius. 1977. Distribution of artificial tritium in firn samples from East Antarctica. International Association of Hydrological Sciences Publication 118 (Symposium at Grenoble 1975Isotopes and Impurities in Snow and Ice), 138-145.

Mulvaney, R. and E.W. Wolff. 1994. Spatial variability of the major chemistry of the Antarctic ice sheet. Ann. Glaciol., 20, 440-447.

Parker, B. C., E. J. Zeller and A. J. Gow. 1982. Nitrate fluctuations in Antarctic snow and firn: potential sources and mechanisms of formation. Ann. Glaciol., 3, 243-248.

Pettré, P., J. F. Pinglot, M. Pourchet and L. Reynaud. 1986. Accumulation distribution in Terre Adélie, Antarctica: effect of meteorological parameters. 7. Glaciol., 32(112), 486-500.

Pszenny, A. A. P. 1992. Particle size distributions of methanesulphonate in the tropical Pacific marine boundary layer. 7. Atmos. Chem., 14(1-4), 273-284.

Pszenny, A. A. P., A. J. Castelle, J. N. Galloway and R. A. Duce. 1989. A study of the sulfur cycle in the Antarctic marine boundary layer. 7. Geophys. Res., 94(D7), 9818-9830.

Qin Dahe. 1995. Report on glaciological research of the 1990 International TransAntarctic Expedition (1989-1994).] Beijing, Science Press. Chinese Academy of Sciences. Lanzhou Institute of Glaciology and Geocryology. [In Chinese.]

Qin Dahe, E. J. Zeller and G. A. M. Dreschhoff. 1992. The distribution of nitrate content in the surface snow of the Antarctic ice sheet along the route of the 1990 International Trans-Antarctic Expedition. 7. Geophys. Res., 97(A5), 6277-6284.

Qin Dahe, J. R. Petit, J. Jouzel and M. Stievenard. 1994. Distribution of stable isotopes in surface snow along the route of the 1990 International Trans-Antarctica Expedition. f. Glaciol., 40(134), 107-118.

Rémy, F., P. Shaeffer and B. Legrésy. 1999. Ice flow physical processes derived from ERS-1 high-resolution map of Antarctica and Greenland ice sheet. Geophys. F. Int., 139(3), 645-656.

Saigne, C. and M. Legrand. 1987. Measurements of methanesulphonic acid in Antarctic ice. Nature, 330(6145), 240-242.

Saltzman, E. S., D. L. Savoie, R. G. Zika and J. M. Prospero. 1983. Methane sulfonic acid in the marine atmosphere. F. Geophys. Res., 88(C15), 10,897-10,902.

Saltzman, E. S., D. L. Savoie, J. M. Prospero and R. G. Zika. 1986. Methanesulphonic acid and non-sea-salt sulphate in Pacific air: regional and seasonal variations. 7. Atmos. Chem., 4(3), 227-240.

Stenberg, M. and 7 others. 1998. Spatial variability of snow chemistry in western Dronning Maud Land, Antarctica. Ann. Glaciol., 27, 378-384.

Stenni, B. and 6 others. 2000. Snow accumulation rates in northern Victoria Land, Antarctica, by firn-core analysis. 7. Glaciol., 46(155), 541-552.

Stenni, B. and 6 others. 2002. Eight centuries of volcanic signal and climate change at Talos Dome (East Antarctica). 7. Geophys. Res., 107(D9). (10.1029/2000JD000317.

Traversi, R., S. Becagli, E. Castellano, O. Largiuni and R. Udisti. 2000 Stability of chemical species in firn layers from Antarctica. In Colacino, M. and G. Giovannelli, eds. 8th Workshop, Italian Research on the Antartic Atmosphere. Proceedings. Vol. 69. Bologna, Società Italiana di Fisica, 421-443.

Udisti, R., R. Traversi, S. Becagli and G. Piccardi. 1998. Spatial distribution and seasonal pattern of biogenic sulphur compounds in snow from northern Victoria Land, Antarctica. Ann. Glaciol., 27, 535-542.

Udisti, R., S. Becagli, E. Castellano, R. Traversi, S. Vermigli and G. Piccardi. 1999. Sea-spray and marine biogenic seasonal contribution to snow composition at Terra Nova Bay, Antarctica. Ann. Glaciol., 29, 77-83.

Urbini, S., S. Gandolfi and L. Vittuari. 2001. GPR and GPS data integration: examples of application in Antarctica. Ann. Geofis., 44(4), 687-702.

Wagnon, P., R. J. Delmas and M. Legrand. 1999. Loss of volatile acid species from upper firn layers at Vostok, Antarctica. 7. Geophys. Res., 104(D3), 3423-3431.

Watanabe, O. 1978. Distribution of surface features of snow cover in Mizuho Plateau. Natl. Inst. Polar Res. Mem., Special Issue 7, 154-181.

Wolff, E.W. 1995. Nitrate in polar ice. In Delmas, R.J., ed. Ice core studies of global biogeochemical cycles. Berlin, etc., Springer-Verlag, 195-224. (NATO ASI Series I: Global Environmental Change 30.)

Wolff, E.W. 1996. Location, movement and reactions of impurities in solid ice. In Wolff, E. W. and R. C. Bales, eds. Chemical exchange between the atmosphere and polar snow. Berlin, etc., Springer-Verlag, 541-560. (NATO ASI Series I: Global Environmental Change 43.)

Zeller, E. and B. C. Parker. 1981. Nitrate ion in Antarctic firn as a marker for solar activity. Geophys. Res. Lett., 8 (8), 895-898. 